\title{
The Relationships between Plant Developmental Traits and Winter Field Survival in Rye (Secale cereale L.)
}

\author{
Hirbod Bahrani ${ }^{1}\left(\right.$, Monica Båga ${ }^{1}$, Jamie Larsen ${ }^{2}$, Robert J. Graf ${ }^{3}$, Andre Laroche ${ }^{3}$ and Ravindra N. Chibbar ${ }^{1, *}$ \\ 1 Department of Plant Sciences, University of Saskatchewan, Saskatoon, SK S7N 5A8, Canada; \\ hib860@mail.usask.ca (H.B.); monica.baga@usask.ca (M.B.) \\ 2 Harrow Research and Development Centre, Agriculture and Agri-Food Canada, \\ Harrow, ON NOR 1G0, Canada; jamie.larsen@canada.ca \\ 3 Lethbridge Research and Development Centre, Agriculture and Agri-Food Canada, \\ Lethbridge, AB T1J 4B1, Canada; robert.graf@canada.ca (R.J.G.); andre.laroche@canada.ca (A.L.) \\ * Correspondence: ravi.chibbar@usask.ca
}

\section{check for}

updates

Citation: Bahrani, H.; Båga, M.; Larsen, J.; Graf, R.J.; Laroche, A.; Chibbar, R.N. The Relationships between Plant Developmental Traits and Winter Field Survival in Rye (Secale cereale L.). Plants 2021, 10, 2455. https://doi.org/10.3390/plants10112455

Academic Editors: Chien Van Ha, Mohammad Golam Mostofa, Gopal Saha and Swarup Roy Choudhury

Received: 14 October 2021 Accepted: 9 November 2021 Published: 13 November 2021

Publisher's Note: MDPI stays neutral with regard to jurisdictional claims in published maps and institutional affiliations.

Copyright: (c) 2021 by the authors. Licensee MDPI, Basel, Switzerland. This article is an open access article distributed under the terms and conditions of the Creative Commons Attribution (CC BY) license (https:/ / creativecommons.org/licenses/by/ $4.0 /)$.

\begin{abstract}
Overwintering cereals accumulate low temperature tolerance (LTT) during cold acclimation in the autumn. Simultaneously, the plants adjust to the colder season by making developmental changes at the shoot apical meristem. These processes lead to higher winter hardiness in winter rye varieties (Secale cereale L.) adapted to Northern latitudes as compared to other cereal crops. To dissect the winter-hardiness trait in rye, a panel of 96 genotypes of different origins and growth habits was assessed for winter field survival (WFS), LTT, and six developmental traits. Best Linear Unbiased Estimates for WFS determined from five field trials correlated strongly with LTT $(\mathrm{r}=0.90$, $p<0.001$ ); thus, cold acclimation efficiency was the major contributor to WFS. WFS also correlated strongly $(p<0.001)$ with final leaf number $(r=0.80)$, prostrate growth habit $(r=0.61)$, plant height $(\mathrm{r}=0.34)$, but showed weaker associations with top internode length $(\mathrm{r}=0.30, p<0.01)$ and days to anthesis $(\mathrm{r}=0.25, p<0.05)$. The heritability estimates $\left(h^{2}\right)$ for WFS-associated traits ranged from 0.45 (prostrate growth habit) to 0.81 (final leaf number) and were overall higher than for WFS $\left(h^{2}=0.48\right)$. All developmental traits associated with WFS and LTT are postulated to be regulated by phytohormone levels at shoot apical meristem.
\end{abstract}

Keywords: winter cereals; winter field survival; low temperature tolerance; final leaf number; plant height; prostrate growth habit

\section{Introduction}

Rye (Secale cereale L.) is an annual grass of the Triticeae tribe within the Pooideae subfamily, which also includes barley (Hordeum vulgare L.), hexaploid wheat (Triticum aestivum L.), and several pasture grasses. The cultivated form of rye (Secale cereale ssp. cereal) is mainly grown in North America, Northern and Eastern Europe, Russia, and China, where the grain is used for animal feed or production of bread and alcoholic beverages. Rye can also be grown for biomass used as forage, green manure, or production of bioenergy [1,2]. Cultivation of rye is traditionally performed with open-pollinated breeding populations, but they are gradually being replaced by hybrid varieties producing higher yields due to heterosis effects [3]. Rye has a relatively high drought tolerance due to a well-developed root system and is therefore often cultivated on marginal land that is unsuitable for most other cereal crops [4]. The undemanding nature of rye is an important asset for future development of new varieties that will withstand the effects of climate change.

The growth habit of annual temperate cereals can broadly be divided into winter, facultative, and spring types, which differ in seeding time due to variation in vernalization and photoperiod sensitivities. The most commonly grown rye varieties are autumn-seeded, frost-tolerant winter types, which have a vernalization requirement prior to winter and flower when long days and warmer temperature return in the spring. Facultative types, 
sown in the spring or autumn, are photoperiod sensitive, lack vernalization requirement, but can develop low temperature tolerance (LTT) by cold acclimation [5]. Spring-seeded genotypes lack or have very low vernalization requirement, and thus are established and set seed in a single growing season. In contrast to annual rye, vernalization-dependent perennial rye (Secale cereale $\times$ Secale strictum) re-enters a vegetative state after seed set, which is a growth habit dependent on both environmental and genetic factors [6].

Vernalization in Triticeae winter types is required for flowering competency and it is induced by low, nonfreezing temperatures in the autumn. The process is largely controlled by the VERNALIZATION 1 (VRN1) and VRN2 genes that are part of the VRN1-VRN2-VRN3 regulatory module [7-11]. Cold exposure leads to vernalization saturation characterized by induction of VRN1 expression at shoot apical meristem (SAM) and leaves, whereas $V R N 2$, the main repressor of flowering, becomes down-regulated $[9,12,13]$. At vernalization saturation in the late autumn, SAM switches from vegetative to reproductive growth [14] and VRN1 and VRN3 are imprinted with an epigenetic 'memory of cold' that is maintained throughout vegetative plant growth [15]. The identification of Arabidopsis FLOWERING LOCUS C (FLC)-like genes in monocots with demonstrated roles during vernalization $[8,16-18]$ has complicated the original $V R N$ regulatory model and a full understanding of the vernalization process has not been obtained [19].

The low temperature-induced cold acclimation is a process genetically linked to vernalization [20,21]. Many cryoprotective compounds are produced during cold acclimation, which readjust metabolism, photosynthesis, and membrane composition to build up LTT prior to winter [22-24]. A cluster of C-REPEAT BINDING FACTOR (CBF) genes at Frost Resistance 2 (FR-2) locus on homoeologous group 5 chromosomes in Triticeae species induce many cold-responsive (COR) genes during cold acclimation [25-27]. Genetic factors influencing vernalization sensitivity, photoperiod (day length) response, and cold acclimation efficiency affect winter field survival (WFS) potential in cereals [28].

Rye is a good model crop to study WFS as certain rye varieties adapted to northern latitudes exhibit the strongest vernalization requirement, highest cold acclimation efficiency, and highest WFS among cereals [29]. Determination of WFS levels in cereals is generally achieved by multi-year trials, which are time-consuming and subject to large year-to-year variations due to environmental factors. However, an approximation of LTT developed prior to winter can be obtained by controlled freezing tests performed on cold acclimated crown tissues [14] or plantlets [30]. The accumulated LTT in late autumn gradually declines during winter at a rate determined by the plants de-acclimation resilience and environmental factors such as the amount of snow cover, number of freeze-thaw incidents, and freezing temperatures at crown level [31]. Snow mold infections can also cause LTT decline, thus drastically reduce WFS in locations with long-lasting wet cool weather and deep snow coverage [32]. Production of winter cereals is expected to become more challenging in the future as the winter temperatures become more variable and unpredictable due to global warming [33,34]. Thus, de-acclimation resistance and ability to combat fungal infections will become important components of WFS for winter cereals [31,32].

In winter wheat, the cold acclimation process is highly integrated with the developmental program of the plant [35-37]. This is demonstrated by many genotypes with high vernalization requirement exhibiting a long cold acclimation process, whereby a prostrate growth habit (PGH) is developed and a high number of leaf primordia are initiated at SAM, which lead to high final leaf number (FLN) at maturity $[14,35,37]$. The PGH displayed prior to winter is an adaptive response proposed to suppress weed growth, reduce water evaporation from soil, increase photosynthetic efficiency, and allow plants to benefit from warmer temperature and reduced wind exposure at ground level [38,39]. During reproductive growth in the spring, the winter-hardy cereals have tendency to flower late, grow tall and produce small and narrow leaves [37].

The flag leaf provides most of the photosynthate required for grain filling in wheat cultivars [40]. However, the rye flag leaf area (FLA) is relatively small and occupies only $15-20 \%$ of the total photosynthetic area of the plant [4]. As most open-pollinated rye vari- 
eties are tall (about 120-150 cm), the photosynthetic area of stem becomes highly significant (60-80\% of total) and stem is therefore considered the main producer of photosynthate for grain filling [4]. The top internode (peduncle) elongates last during stem growth and has a major influence on the final plant height (PHT) [41,42]. Tall plants are generally desired for biomass production [1], but less advantageous for grain production as long peduncles can cause lodging with negative effects on grain quality and yield. Reduction in plant height in rye by introgression of dwarfing genes, such as Ddw1 [43], have not resulted in similar yield increases obtained by semi-dwarf wheat [44], which commonly carries various height-reducing alleles [45,46]. Observations in winter wheat support semi-dwarfing genes do not negatively influence LTT [37]; thus, the search for new sources of height-reducing genes for winter rye continues.

In this study, a rye panel of 96 genotypes of diverse geographic regions, growth habits, and winter hardiness levels was analyzed for WFS during five years of field trials. The genotypes were also assessed for LTT ( $\mathrm{LT}_{50}$ values) and six developmental traits to characterize their association with WFS. The results showed that LTT contributed most to high WFS, and several of the plant developmental traits showed very strong association with WFS and LTT.

\section{Results}

\subsection{A Multi-Trait Approach to Study WFS}

In this study, WFS in a rye population of 96 rye genotypes (Table 1) was studied during five years of field tests (Figure S1). To dissect the main trait further, we assessed traits associated with WFS, which is a strategy that can be very informative when analyzing complex traits [47]. Therefore, the WFS studies were accompanied by determinations of LTT, FLN, PGH, days to anthesis (DTA), and PHT, which associate with winter hardiness in certain winter wheat genotypes $[14,35,37]$. Additionally, top internode length (TIL) and flag leaf area (FLA), which are not commonly related to WFS, were also analyzed. Phenotyping of LTT and the developmental traits is relatively easy to accomplish when compared to WFS, which can vary largely from year to year due to abiotic and biotic stress factors affecting plant survival from the early seedling stage in autumn to spring regrowth.

\subsection{WFS for Rye Population Displayed Large Variations between Years}

During the five-year field trials performed at Saskatoon, Canada, the snow cover and winter temperatures were highly variable between years (Table S1). The highest WFS was obtained during the 2015/2016 growing season (92.6\% average WFS; Figure S1), which provided adequate snow cover and a relatively mild winter.

Table 1. Rye genotypes used in the study and their WFS and $\mathrm{LT}_{50}$ scores.

\begin{tabular}{|c|c|c|c|c|}
\hline $\begin{array}{c}\text { Winter Survival Class: } \\
\text { Genotype }\end{array}$ & Origin & Growth Habit & $\begin{array}{c}\text { WFS } \\
\text { BLUE Score * }\end{array}$ & $\mathrm{LT}_{50}$ Value $\left({ }^{\circ} \mathrm{C}\right)$ \\
\hline \multicolumn{5}{|l|}{ Very high: } \\
\hline Leth Coulee Rye & Canada & Winter & 92.5 & -26.8 \\
\hline Gauthier & Canada & Winter & 90.1 & -26.2 \\
\hline AC Remington & Canada & Winter & 86.2 & -27.0 \\
\hline AC Rifle & Canada & Winter & 85.9 & -27.0 \\
\hline Musketeer & Canada & Winter & 83.0 & -27.8 \\
\hline SM 38R & Canada & Winter & 77.5 & -24.0 \\
\hline Prima & Canada & Winter & 77.0 & -27.5 \\
\hline Saratovskaja 4 & Russia & Winter & 71.8 & -26.8 \\
\hline SM 4R & Canada & Winter & 71.0 & -26.8 \\
\hline Pearl & Denmark & Winter & 69.5 & -26.6 \\
\hline Kustro & Canada & Winter & 68.8 & -25.8 \\
\hline Kharkivska 95 & Ukraine & Winter & 67.9 & -24.8 \\
\hline Kharkivska 98 & Ukraine & Winter & 66.9 & -24.0 \\
\hline Esprit & Germany & Winter & 66.3 & -22.8 \\
\hline
\end{tabular}


Table 1. Cont

\begin{tabular}{|c|c|c|c|c|}
\hline $\begin{array}{c}\text { Winter Survival Class: } \\
\text { Genotype }\end{array}$ & Origin & Growth Habit & $\begin{array}{c}\text { WFS } \\
\text { BLUE Score * }\end{array}$ & $\mathbf{L T}_{50}$ Value $\left({ }^{\circ} \mathrm{C}\right)$ \\
\hline \multicolumn{5}{|l|}{ Very high: } \\
\hline Ponsi & Sweden & Winter & 66.0 & -24.8 \\
\hline Hazlet & Canada & Winter & 65.5 & -23.6 \\
\hline Antelope & Canada & Winter & 65.3 & -26.2 \\
\hline Emerald & USA & Winter & 65.2 & -22.0 \\
\hline Anna & Finland & Winter & 64.5 & -22.0 \\
\hline \multicolumn{5}{|l|}{ High: } \\
\hline R003-4 & Canada & Winter & 64.3 & -24.0 \\
\hline Voima & Finland & Winter & 64.2 & -23.8 \\
\hline Dakota & Canada & Winter & 64.1 & -26.7 \\
\hline Sc-73 & Canada & Winter & 64.0 & -22.4 \\
\hline Animo & Netherlands & Winter & 63.6 & -25.2 \\
\hline Caribou & Canada & Winter & 63.6 & -23.8 \\
\hline Puma & Canada & Winter & 62.4 & -26.0 \\
\hline Othello & Sweden & Winter & 62.2 & -22.0 \\
\hline Rymin & USA & Winter & 61.9 & -23.4 \\
\hline Adams & USA & Winter & 61.5 & -22.8 \\
\hline Sangaste & Estonia & Winter & 60.3 & -23.0 \\
\hline Visa & Finland & Winter & 59.9 & -24.2 \\
\hline Vitallo & Germany & Winter & 59.6 & -23.5 \\
\hline Halo & Germany & Winter & 59.5 & -26.2 \\
\hline Balbo & Italy & Facultative & 59.4 & -26.0 \\
\hline Frontier & Canada & Winter & 58.6 & -24.4 \\
\hline Enzi & Finland & Winter & 58.4 & -22.0 \\
\hline Explorer & USA & Facultative & 58.4 & -23.4 \\
\hline Motto & Poland & Winter & 58.0 & -23.6 \\
\hline Dankowskie Selekcyjne & Poland & Winter & 56.7 & -23.8 \\
\hline \multicolumn{5}{|l|}{ Moderate: } \\
\hline Galma & Belgium & Winter & 56.6 & -22.6 \\
\hline Cougar & Canada & Winter & 56.1 & -24.0 \\
\hline Dominant & Netherlands & Winter & 55.8 & -23.6 \\
\hline Dankowskie Nowe & Poland & Winter & 54.9 & -24.6 \\
\hline Danko & Canada & Winter & 54.2 & -24.8 \\
\hline ACE-1 & Canada & Perennial & 54.0 & -19.4 \\
\hline Dankowskie Srebrne & Poland & Winter & 53.9 & -24.2 \\
\hline Carolkurz & Germany & Winter & 53.2 & -23.8 \\
\hline Horton & Canada & Winter & 53.1 & -24.0 \\
\hline Kodiak & Canada & Winter & 51.8 & -25.0 \\
\hline GC-100 & Russia & Winter & 51.6 & -23.0 \\
\hline Amilo & Poland & Winter & 49.2 & -20.8 \\
\hline Sellino & Germany & Winter & 48.5 & -21.8 \\
\hline R538 & UK & Perennial & 48.1 & -21.6 \\
\hline Protector & Germany & Winter & 47.8 & -22.4 \\
\hline Toivo & Finland & Winter & 47.5 & -23.8 \\
\hline Culpan & Russia & Winter & 47.0 & -22.6 \\
\hline Hardy white spring Rye & Austria & Winter & 46.9 & -21.6 \\
\hline Maton & USA & Facultative & 46.2 & -19.5 \\
\hline \multicolumn{5}{|l|}{ Low: } \\
\hline Stoir & Ukraine & Winter & 43.7 & -22.2 \\
\hline Vaschod & Belarus & Winter & 43.7 & -21.2 \\
\hline R550 & Czech Republic & Perennial & 43.6 & -21.4 \\
\hline Reimann Philipp & Germany & Perennial & 42.4 & -21.0 \\
\hline Oklon & USA & Facultative & 40.9 & -19.6 \\
\hline Carsten & Germany & Winter & 39.5 & -18.0 \\
\hline R903 & Unknown & Perennial & 38.9 & -22.0 \\
\hline Harach & Canada & Spring & 38.8 & -21.4 \\
\hline Danae & Germany & Winter & 37.1 & -21.2 \\
\hline Clse 35 & USA & Winter & 36.8 & -20.2 \\
\hline
\end{tabular}


Table 1. Cont.

\begin{tabular}{|c|c|c|c|c|}
\hline $\begin{array}{c}\text { Winter Survival Class: } \\
\text { Genotype }\end{array}$ & Origin & Growth Habit & $\begin{array}{c}\text { WFS } \\
\text { BLUE Score * }\end{array}$ & $\mathbf{L T}_{50}$ Value $\left({ }^{\circ} \mathrm{C}\right)$ \\
\hline \multicolumn{5}{|l|}{ Low: } \\
\hline Gator & USA & Facultative & 36.0 & -23.2 \\
\hline Elbon & USA & Facultative & 35.9 & -17.0 \\
\hline L-286-R & Germany & Winter & 35.7 & -16.4 \\
\hline R904 & Unknown & Perennial & 35.4 & -19.8 \\
\hline Syn $20-\mathrm{L}$ & Germany & Winter & 35.3 & -21.8 \\
\hline SR4A-S5 & Canada & Spring & 33.2 & -17.6 \\
\hline Dakold & USA & Winter & 31.1 & -20.5 \\
\hline Wheeler & USA & Winter & 31.0 & -20.8 \\
\hline M.Karlic CT2 & Russia & Winter & 30.5 & -19.5 \\
\hline \multicolumn{5}{|l|}{ Very low: } \\
\hline Wintergrazer 70 & USA & Facultative & 25.2 & -20.2 \\
\hline Petkus Kurzstroh & Germany & Winter & 24.1 & -19.0 \\
\hline Gazelle & Canada & Spring & 23.6 & -19.0 \\
\hline Petkus & Germany & Winter & 22.9 & -21.2 \\
\hline Prolific Spring & Canada & Spring & 22.1 & -19.2 \\
\hline Wren Abruzzi & USA & Facultative & 20.0 & -18.0 \\
\hline Extra Early Rye1 & Mexico & Spring & 19.7 & -16.4 \\
\hline Somro & Germany & Winter & 16.0 & -18.8 \\
\hline $\mathrm{R} 1210$ & South Africa & Perennial & 15.7 & -16.0 \\
\hline Baltia & Russia & Winter & 15.6 & -16.8 \\
\hline R797 & Poland & Perennial & 13.2 & -16.0 \\
\hline Fl-Synt & USA & Spring & 12.9 & -16.4 \\
\hline Ottawa Select & Canada & Winter & 12.9 & -16.8 \\
\hline Gulzow Kunz CT1 & Germany & Winter & 12.4 & -16.2 \\
\hline Rogo & Germany & Spring & 12.4 & -16.2 \\
\hline Florida 401 & USA & Spring & 7.1 & -15.8 \\
\hline L-145-N & Germany & Winter & 0.0 & -17.0 \\
\hline L-145-P & Germany & Winter & 0.0 & -16.5 \\
\hline L-18-R & Germany & Winter & 0.0 & -16.5 \\
\hline
\end{tabular}

*WFS data from five field trials; includes previous data from four trials [48].

In contrast, survival upon the $2017 / 2018$ winter season was very low $(6.8 \%$ average WFS) due to deeper and longer cold spells and occasional poor snow cover. The remaining trials in 2014/15, 2016/17, and 2018/19 provide a desired wide distribution of WFS values within the population. Despite the challenges with WFS phenotyping in certain years, most of the WFS data from the trials were significantly correlated (Table 2). The 2016/2017 and 2018/2019 trials showed the strongest correlation $(\mathrm{r}=0.67, p<0.001)$, whereas the $2015 / 2016$ and $2017 / 2018$ trials did not significantly correlate with each other $(r=0.17$, $p>0.05)$.

The BLUEs calculated for WFS from all five trials ranged from 0.0 to $92.5 \%$ (Table 1 ) with a mean of $47.7 \%$ (Figure 1A). The correlation value between WFS_BLUEs and the WFS values for the five individual trials were highly significant $(p<0.001)$ and ranged from 0.59 to 0.91 and were overall higher than observed between the individual trials (Table 2). Winter types, as expected, showed the highest WFS (WFS_BLUE = 0.0-92.5\%; mean $=52.8 \%)$, followed by facultative types $(20.0-59.4 \%$; mean $=40.3 \%)$, perennial types $(13.2-54.0 \%$; mean $=36.4 \%)$, and spring types $(7.1-38.8 \%$; mean $=21.2 \%)$ (Table 1$)$. From the WFS_BLUEs, five WFS classes were defined for the rye panel: (i) very high $(64.5-92.5 \%$; 19 genotypes), (ii) high (56.7-64.3\%; 20 genotypes), (iii) moderate (46.2-56.6\%; 19 genotypes), (iv) low (30.5-43.7\%; 19 genotypes), and (v) very low (0.0-25.2\%; 19 genotypes) (Table 1). Eleven of the nineteen genotypes within the very high WFS class were winter types adapted to the cold Canadian winters (Leth Coulee Rye, Gauthier, AC Remington, AC Rifle, Musketeer, SM 38R, Prima, SM 4R, Kustro, Hazlet, and Antilope). Carsten and Petkus, which have frequently been used for cultivation and breeding in Europe [4], were placed in the low and very low WFS classes, respectively (Table 1). 
Table 2. Correlations between LTT and WFS.

\begin{tabular}{ccccccc}
\hline Trait & WFS 2014/15 & WFS 2015/16 & WFS 2016/17 & WFS 2017/18 & WFS 2018/19 & WFS-BLUE \\
\hline Low temperature tolerance (LTT) & $0.70^{* * *}$ & $0.62^{* * *}$ & $0.82^{* * *}$ & $0.54^{* * *}$ & $0.81^{* * *}$ & $0.90^{* * *}$ \\
Winter field survival 2014/15 & & $0.44^{* *}$ & $0.54^{* * *}$ & $0.37^{* *}$ & $0.63^{* * *}$ & $0.66^{* * *}$ \\
Winter field survival 2015/16 & & & $0.66^{* * *}$ & $0.17^{* * *}$ & $0.49^{* * *}$ & $0.76^{* * *}$ \\
Winter field survival 2016/17 & & & & $0.36^{* *}$ & $0.67^{* * *}$ & $0.91^{* * *}$ \\
Winter field survival 2017/18 & & & & $0.58^{* * *}$ & $0.59^{* * *}$ \\
Winter field survival 2018/19 & & & & & $0.88^{* * *}$ \\
Winter field survival BLUE score ${ }^{2}$ & & & & & \\
\hline
\end{tabular}

${ }^{1}$ LTT is defined as negative $\mathrm{LT}_{50}$ value; ${ }^{2}$ BLUE score determined from five WFS trials. ${ }^{* *}$ significance of Pearson correlation coefficient $p<0.01 ; * * * 0.001$.

A.

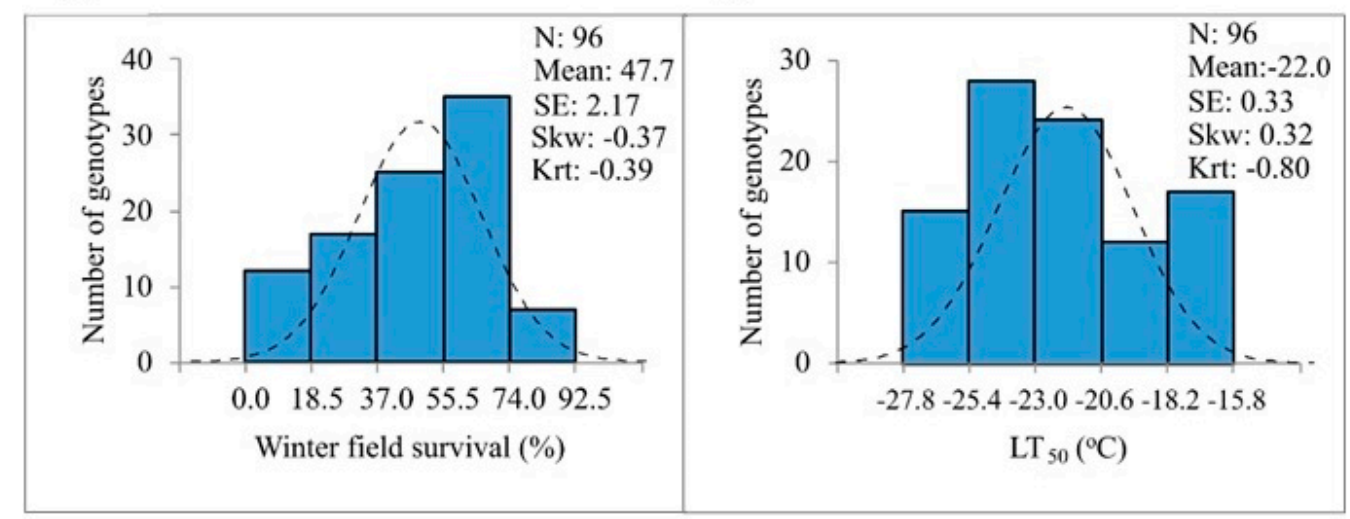

Figure 1. Distribution of frost hardiness determined for rye population of 96 accessions. (A) WFS (BLUE scores) determined from five years of field trials; (B) average $\mathrm{LT}_{50}$ values determined from controlled freezing tests.

\subsection{Freezing Tests Provided a Good Estimate of WFS Levels for the Rye Genotypes}

One component of WFS is LTT built up during cold acclimation prior to winter and this trait was estimated by controlled freezing tests. Cold-hardy wheat cultivar Norstar used as a control in the tests showed an average $\mathrm{LT}_{50}$ value of $-21.4{ }^{\circ} \mathrm{C}$, whereas higher LTT (lower $\mathrm{LT}_{50}$ values) was noted for 59 out of $96(61 \%)$ rye genotypes tested (Table 1). Genotypes of the very high WFS class had the highest $\mathrm{LTT}\left(\mathrm{LT}_{50}\right.$ mean $\left.=-25.4{ }^{\circ} \mathrm{C}\right)$ and a gradual decrease in average LTT was seen for the following WFS classes: high WFS $\left(\mathrm{LT}_{50}\right.$ mean $\left.=-24.0^{\circ} \mathrm{C}\right)$, moderate WFS $\left(\mathrm{LT}_{50}\right.$ mean $\left.=-22.8^{\circ} \mathrm{C}\right)$, low WFS $\left(\mathrm{LT}_{50}\right.$ mean $\left.=-20.3^{\circ} \mathrm{C}\right)$ and very low WFS $\left(\mathrm{LT}_{50}\right.$ mean $\left.=-17.5^{\circ} \mathrm{C}\right)($ Table 1$)$. Like the WFS distribution, the absolute skewness and kurtosis values for $\mathrm{LT}_{50}$ distribution were $<1.0$, which was indicative of continuous trait variation within the population (Figure $1 \mathrm{~A}, \mathrm{~B}$ ).

The freezing test data for the rye population confirmed winter types developed the lowest $\mathrm{LT}_{50}$ values (e.g., highest LTT) during cold acclimation (Table 1) and highest LTT was noted among the most winter-hardy genotypes such as Canadian cultivars Musketeer $\left(\mathrm{LT}_{50}=-27.8^{\circ} \mathrm{C}\right)$, Prima $\left(\mathrm{LT}_{50}=-27.5^{\circ} \mathrm{C}\right), \mathrm{AC}$ Remington $\left(\mathrm{LT}_{50}=-27.0^{\circ} \mathrm{C}\right)$, and AC Rifle $\left(\mathrm{LT}_{50}=-27.0^{\circ} \mathrm{C}\right)$. However, a few winter types such as Baltia, Ottawa Select, Gulzow Kunz CT1, and three highly inbred lines (94-L-145-N, 95-L-145-P, and 96-L-18-R) exhibited very low $\mathrm{LTT}\left(\mathrm{LT}_{50}>-17.0^{\circ} \mathrm{C}\right)$ and also survived poorly in the field (WFS_BLUE < 15.6\%) (Table 1). The facultative genotypes in the study showed overall low WFS with the exception of the genotypes Balbo $\left(\right.$ WFS_BLUE $=59.4 \% ; \mathrm{LT}_{50}=-26.0^{\circ} \mathrm{C}$ ) and Explorer (WFS_BLUE $=58.4 \%$; $\mathrm{LT}_{50}=-23.4{ }^{\circ} \mathrm{C}$ ), which were included in the high WFS class (Table 1). Among the perennial genotypes, the Canadian ACE-1 developed for pasture and silage production [49] performed best, but did not accumulate adequate winter hardiness prior to winter to survive well on the Canadian Prairies (WFS_BLUE $=54.0 \%$; $\mathrm{LT}_{50}=-19.4{ }^{\circ} \mathrm{C}$; Table 1). As expected, the lowest WFS and LTT were recorded for spring 
genotypes (WFS_BLUE $\leq 38.8 \%$; $\mathrm{LT}_{50} \geq-21.4{ }^{\circ} \mathrm{C}$; Table 1 ), for which seven out of eight genotypes did not survive the 2017/18 winter (data not shown). Overall, LTT determined for the rye population showed very high correlation with WFS_BLUEs $(r=0.90 ; p<0.001$; Table 3).

Table 3. Correlations between WFS, LTT, and developmental traits.

\begin{tabular}{|c|c|c|c|c|c|c|c|}
\hline & LTT & FLN & PGH & DTA & PHT & TIL & FLA \\
\hline Winter field survival (WFS) ${ }^{1}$ & $0.90^{* * *}$ & $0.80 * * *$ & $0.61 * * *$ & $0.25 *$ & $0.34^{* * *}$ & $0.30 * *$ & 0.13 \\
\hline Low temperature tolerance (LTT) ${ }^{2}$ & & $0.71^{* * *}$ & $0.59 * * *$ & 0.17 & $0.39^{* * *}$ & $0.36^{* * *}$ & 0.14 \\
\hline Final leaf number (FLN) ${ }^{1}$ & & & $0.43^{* * *}$ & 0.14 & $0.28 * *$ & $0.26 *$ & 0.11 \\
\hline Prostrate growth habit (PGH) ${ }^{1}$ & & & & $0.43^{* * *}$ & 0.03 & 0.06 & 0.11 \\
\hline Days to anthesis (DTA) ${ }^{1}$ & & & & & $-0.29 * *$ & -0.25 * & 0.13 \\
\hline Plant height (PHT) ${ }^{1}$ & & & & & & $0.72^{* * *}$ & 0.05 \\
\hline Top internode length (TIL) ${ }^{1}$ & & & & & & & 0.05 \\
\hline Flag leaf area (FLA) ${ }^{1}$ & & & & & & & \\
\hline
\end{tabular}

${ }^{1}$ BLUE scores. ${ }^{2}$ Negative $\mathrm{LT}_{50}$ values. Pearson correlation coefficient were determined at ${ }^{*} p<0.05 ;{ }^{* *} p<0.01$; ${ }^{* * *} p<0.001$.

\subsection{FLN and PGH Values Were Strongly Associated with WFS}

Among the rye genotypes FLN_BLUEs varied from 7.7 to 12.4 leaves per plant with a mean 9.6 leaves (Figure 2 and Figure S2; Table S2). High FLN ( $>11$ leaves) was observed for 11 genotypes of the very high WFS class (19 genotypes), whereas all genotypes within the very low WFS class (19 genotypes) produced less than nine leaves (Table S2). Perennial, facultative and spring genotypes had overall lower FLN than winter types (Table S2). Rye genotypes Musketeer, AC Rifle, AC Remington with the highest FLN ( $\geq 12.0$ leaves; Table S2) were among the most winter-hardy (WFS $\geq 83 \%$ ) and developed highest LTT during cold acclimation $\left(\mathrm{LT}_{50}<-27.0^{\circ} \mathrm{C}\right)$ (Table 1). In contrast, breeding lines Petkus and Carsten had relatively low FLN (8.0 and 8.6, respectively; Table S2) combined with low winter-hardiness and relatively high $\mathrm{LT}_{50}$ values (Table 1 ). The FLN values determined for the rye population were strongly associated $(p<0.001)$ with WFS $(r=0.80)$ and LTT $(\mathrm{r}=0.71)$ values, respectively (Table 3$)$.

For individual plants, PGH was determined by visual scoring of cold-acclimated plants for their growth habit according to a scale ranging from erect (1), intermediate (2), or clearly prostrate (3) (Figure S3). Data from the four trials generated PGH_BLUE values ranging from 1.0 to 3.1 with an average of 2.1 for the rye population (Figure 2 and Figure S3). The winter and perennial genotypes showed overall higher PGH scores (mean 2.1) than the facultative and spring types (mean $\sim 1.6$; Table S2). PGH showed strong correlations $(p<0.001)$ with WFS $(r=0.61)$, LTT $(r=0.59)$, FLN $(r=0.43)$, and DTA $(r=0.43)$ (Table 3$)$.

\subsection{Delayed Anthesis Time Was Weakly Associated with Higher WFS}

The plants that had undergone vernalization under controlled conditions were used to determine DTA, by counting the days from the end of cold acclimation to the start of anthesis. Values ranging from 15.3 to 48.8 days with a mean of 31.4 days were obtained for the rye population (Figure 2 and Figure S4; Table S2). With the exception of genotype SR4A-S5, the spring lines flowered early (DTA $<26$ days) and the longest delay to flowering was noted for the perennial genotypes, which all needed at least 34 days to reach anthesis (Table S2). DTA showed relatively weak association with WFS $(\mathrm{r}=0.25, p<0.05)$, but no significant association with LTT, and was negatively associated with both PHT ( $\mathrm{r}=-0.29$, $p<0.01)$ and TIL $(r=-0.25, p<0.05)$ (Table 3$)$. However, a relatively strong association $(p<0.001)$ was noted between DTA and PGH $(r=0.43$; Table 3$)$. 


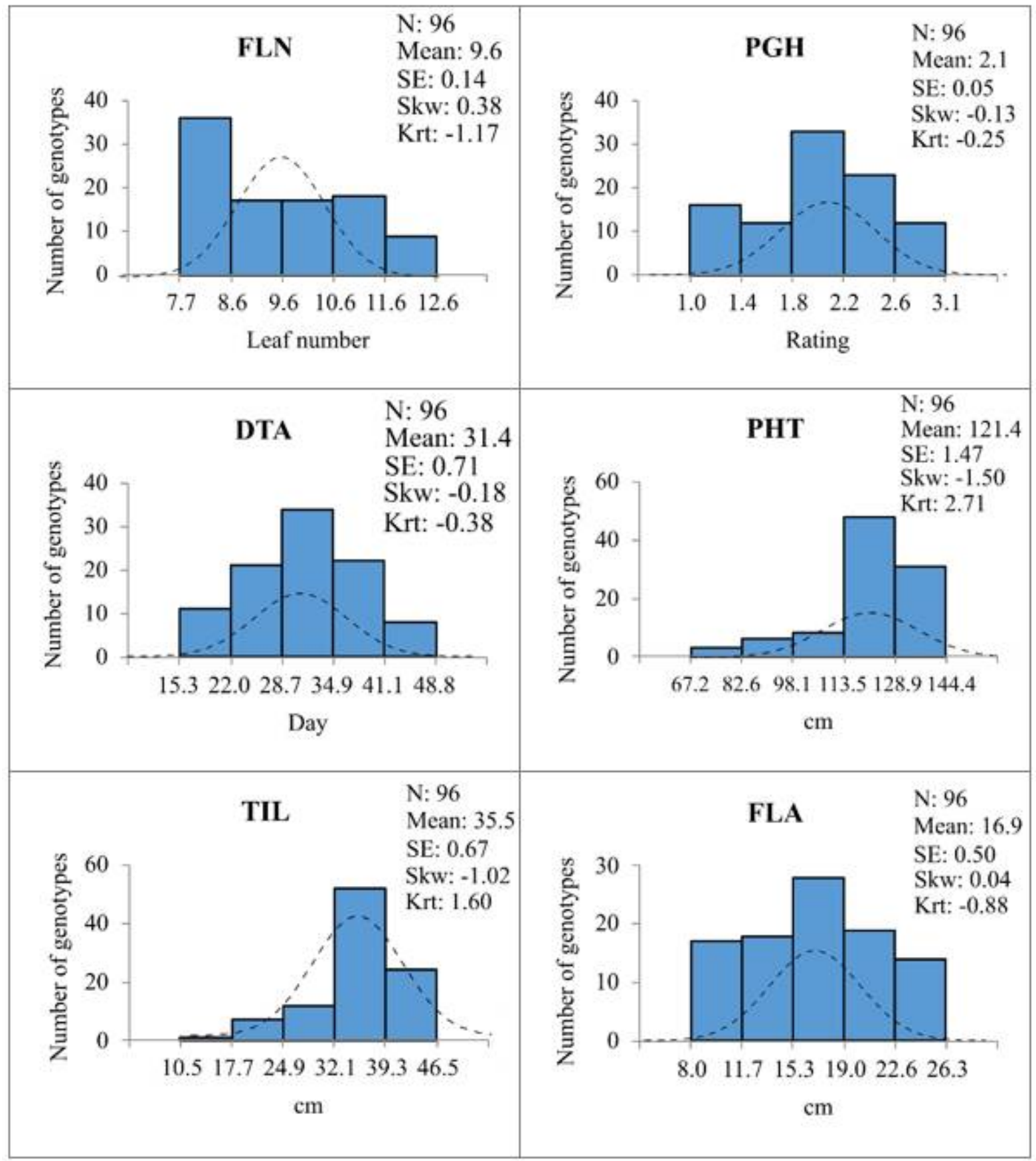

Figure 2. Distribution of developmental trait values for rye population of 96 accessions. Histograms show BLUE scores calculated for final leaf number (FLN), prostrate growth habit (PGH), days to anthesis (DTA), plant height (PHT), top internode length (TIL), and flag leaf area (FLA) determined from four independent trials.

\subsection{Higher WFS Was Associated with Genotypes Growing Tall}

Data from four trials were used to calculate PHT_BLUEs and TIL-BLUEs (Figure S5 and S6) and were found to be highly correlated ( $p=0.001 ; \mathrm{r}=0.72$; Table 3 ). The PHT_BLUEs varied from 62.7 to $144.4 \mathrm{~cm}$ with a mean of $121.4 \mathrm{~cm}$ and variation for TIL_BLUEs ranged from 10.5 to $46.5 \mathrm{~cm}$ with a mean of $35.5 \mathrm{~cm}$ (Figure 2; Table S2). TIL values constituted 15.6 to $38.3 \%$ of the total height for the rye genotypes. Genotypes of short stature $(\mathrm{PHT}<100 \mathrm{~cm})$ were only identified among the spring and winter types (Table S2). Both PHT and TIL showed similar associations with WFS $(\mathrm{r}=0.34, p<0.001$ versus $0.30, p<0.01)$ and LTT $(\mathrm{r}=0.39$ versus $0.36, p<0.001)($ Table 3$)$. 


\subsection{Variation for FLA Did Not Relate to Winter-Hardiness}

Field grown plants from four trials were used to determine FLA_BLUEs (Figure S7) and showed a normal distribution with areas varying from 8.0 to $26.3 \mathrm{~cm}^{2}$ and a mean of $16.9 \mathrm{~cm}^{2}$ (Figure 2; Table S2). FLA showed no significant $(p<0.05)$ association with any of the other traits studied (Table 3), and thus did not seem to be affected by factors controlling cold acclimation.

\subsection{Bi-Plot PCA Supported WFS Is Primarily Determined by Developments at SAM during Cold Acclimation}

In a PCA bi-plot analysis, the first two PCs determined $67.5 \%$ of the total variations for traits studied in the rye population (Figure 3). PC1 accounted for $48.1 \%$ of the total variation and was mainly associated with WFS, LTT, FLN, PGH, and DTA. PC2 with $19.4 \%$ share of total variation was mainly associated with DTA. The PHT and TIL vectors indicated associations with both PC1 and PC2. WFS, LTT, FLN, PGH, and DTA vectors were closely spaced and directed in the same orientation on the bi-plot (Figure 3), which suggested high association as confirmed by the correlation analysis (Table 3). A near right angle between DTA and PHT/TIL vectors in the bi-plot suggested a negative association (Figure 3) that was also supported by the correlation data (Table 3). However, the correlation test did not support a negative association between FLA and TIL as indicated by the bi-plot.

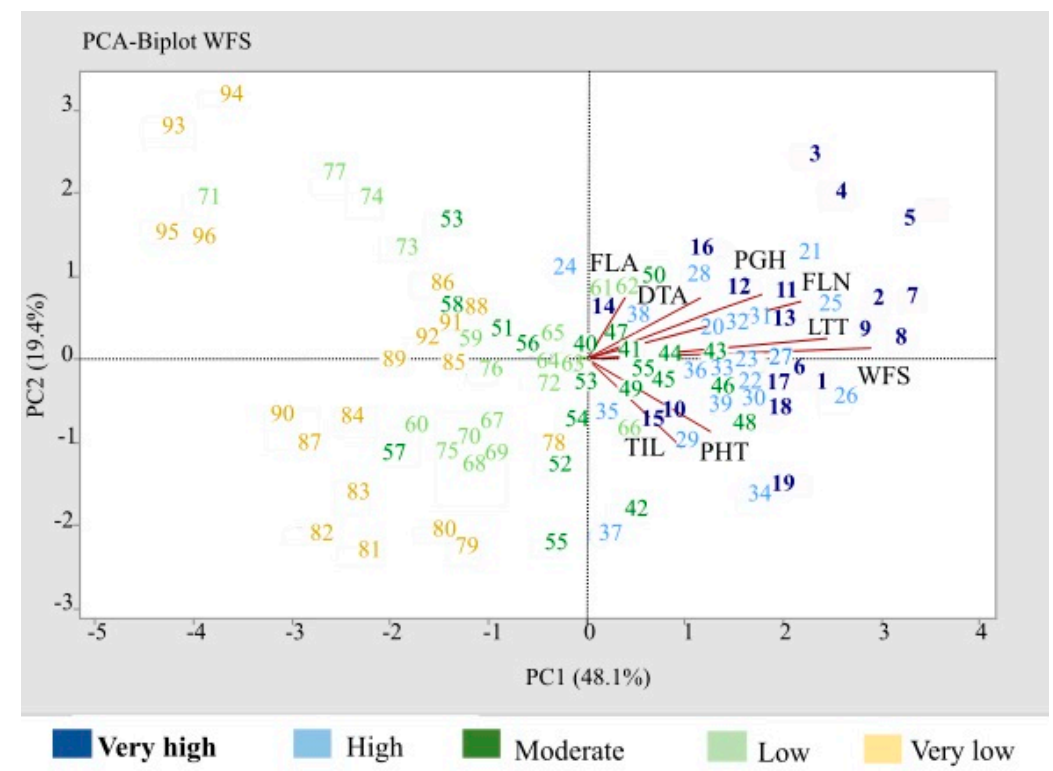

Figure 3. PCA bi-plot of rye genotypes based on PC1 and PC2 components and vectors of traits analyzed in the study. WFS classes for genotypes are indicated by color scheme shown below plot. Genotype numbers refer to Table S2.

Winter genotypes were positioned in all four quadrants (Figure S8), with all of the very high WFS class positioned in the second and third quadrants (Figure 3). Genotypes with low or very low WFS class, including most spring lines, were positioned within the first and fourth quadrants. Perennial genotypes were clustered in the middle, and most facultative genotypes were positioned on the lower half of the plot (Figure S8). FLN, PGH, and DTA vectors were primarily associated with the winter-hardy genotypes in second quadrant, whereas PHT and TIL vectors were mainly directed towards a subgroup of the winter-hardy genotypes positioned in the third quadrant. This subgroup included genotypes from Northern Europe such as Anna, Pearl, and Ponsi, which are relatively tall ( $>133 \mathrm{~cm}$; Table S2). In contrast, most of the winter-hardy Canadian genotypes primarily positioned in the second quadrant appeared to rely more on PGH and FLN traits for their high WFS (Figure 3). 


\subsection{Heritability Estimates Show Genotype Had High Influence on Traits Analyzed}

All traits studied showed significant $(p<0.001)$ effects of genotype $(G)$, environment $(E)$, and genotype $x$ environment $(\mathrm{G} \times \mathrm{E})$ interactions as revealed by an ANOVA analysis (Table 4). The environmental factor was largest for WFS, due to the large variations in winter conditions during the trials (Figure S1). Estimations of broad-sense heritability $\left(h^{2}\right)$ generated values ranging from 0.45 to 0.84 for the different traits (Table 4). Heritability values above 0.6 are generally considered high and were estimated for DTA (0.84), FLN (0.81), FLA (0.76), PHT (0.74), and TIL (0.74). A medium range heritability $(0.30-0.60)$ was estimated for WFS (0.48) and PGH (0.45).

Table 4. Analysis of variance and heritability of WFS and developmental traits.

\begin{tabular}{ccccc}
\hline \multirow{2}{*}{ Trait $^{1}$} & \multicolumn{4}{c}{ Mean Sum of Squares } \\
\cline { 2 - 5 } & Genotype (G) & Environment (E) & G $\times$ E & Heritability $\left(\boldsymbol{h}^{\mathbf{2}}\right)$ \\
\hline Winter field survival (WFS) & $65,990.78^{* * *}$ & $3,303,871.00^{* * *}$ & $13,242.97^{* * *}$ & 0.48 \\
Final leaf number (FLN) & $177.85^{* * *}$ & $196.48^{* * *}$ & $9.30^{* * *}$ & 0.81 \\
Prostrate growth habit (PGH) & $28.02^{* * *}$ & $15.57^{* * *}$ & $6.38^{* * *}$ & 0.45 \\
Days to anthesis (DTA) & $6546.93^{* * *}$ & $2173.40^{* * *}$ & $285.18^{* * *}$ & 0.84 \\
Plant height (PHT) & $23,717.40^{* * *}$ & $15,098.94^{* * *}$ & $1815.25^{* * *}$ & 0.74 \\
Top internode length (TIL) & $4077.32^{* * *}$ & $871.38^{* * *}$ & $314.83^{* * *}$ & 0.74 \\
Flag leaf area (FLA) & $2547.20^{* * *}$ & $1901.13^{* * *}$ & $184.37^{* * *}$ & 0.76 \\
\hline
\end{tabular}

${ }^{1}$ BLUE scores. Pearson correlation coefficient determined at ${ }^{* * *} p<0.001$.

\section{Discussion}

\subsection{Rye Population Studied Provided a Wide Variation of Winter-Hardiness Levels}

Cultivation of winter cereals at Northern latitudes is highly dependent on plant survival during winter, which can drastically affect seed or biomass yields at maturity. Thus, studies on WFS are important for future expansion of winter rye growing areas and production volumes, but also for development of other winter cereals with improved winter hardiness. Winter rye is unique among the temperate cereal crops as it has adapted well to Northern climates, allowing cultivation in areas not suitable for wheat. Thus, the most winter-hardy rye genotypes in the study hold valuable information regarding winter survival during very cold winters in the northern latitudes in Asia, Europe, and North America. In contrast, the tender genotypes in the population were useful for identification of traits not associated with high WFS. A large amount of the frost tolerance variation among cereals depends on copy number and allele differences at the VRN1 and FR-2 loci, respectively, based on studies of diploid and hexaploid wheat [50,51] and barley $[52,53]$. $F r-R 2$ is confirmed as a major frost hardiness locus in rye [54,55], but very little is known about other loci affecting WFS or LTT in rye. In wheat, interactions between VRN1 and $F r-A 2$ alleles modulate cold-induced CBF gene expression that is critical for induction of COR genes and development of high LTT [20]. Thus, the poor WFS displayed by spring rye types in this study is likely due to the lack of vernalization requirement combined with the inability to induce COR gene expression to high levels when exposed to low temperatures in the autumn [56,57].

\subsection{Efficiency of the Cold Acclimation Process Was a Major Factor for WFS}

In the freezing tests, the $\mathrm{LT}_{50}$ values were determined on plants cold acclimated under constant exposure to $4{ }^{\circ} \mathrm{C}$ temperature, low light intensity, and a short-day cycle. These growth room conditions do not include the frequent variations in light intensity and temperature that naturally occur in the field, which constitute environmental signals that can prime plants to increase their cold acclimation [58]. Such triggering events may include a short cold spell prior to a longer period of cold or exposure to slightly subzero temperatures, initiating a second hardening step [30,59]. Despite the differences in cold acclimation conditions under natural and controlled conditions, the determined LTT corre- 
lated relatively well with WFS determined from individual trials $(\mathrm{r}=0.54-0.82 ; p<0.001)$ and particularly well to BLUEs determined for WFS $(r=0.90 ; p<0.001$; Table 2). Thus, the efficiency of the cold acclimation process in the autumn was the major contributing factor to WFS in this study. Previous field tests of winter wheat genotypes performed in the Saskatoon region also demonstrate a very high correlation $(r=0.95)$ between LTT and WFS [37]. Saskatoon winters typically have low humidity levels, thin snow cover, and overall unfavorable conditions for snow mold infections, which can have a large negative impact on WFS $[32,60]$. In locations with long-lasting snow cover and humid conditions at ground level, the correlations between WFS and LTT are expected to be considerably lower than observed in this study.

\subsection{Developments at SAM Were Closely Associated with WFS and LTT}

The rye genotypes Musketeer, AC Rifle, AC Remington with the highest FLN $(\geq 12.0$ leaves; Table S2) were among genotypes with highest WFS (WFS $\geq 83 \%$ ) and highest LTT (lowest $\mathrm{LT}_{50}<-27.0^{\circ} \mathrm{C}$ ) (Table 1). A low FLN demonstrated by breeding lines Petkus and Carsten (8.0 and 8.6, respectively, Table S2) suggested a short cold acclimation process underlies low WFS and LTT for these genotypes. FLN in the rye population was strongly associated $(p<0.001)$ with WFS $(r=0.80)$ and LTT $(r=0.71)$, respectively (Table 3). Thus, the majority of the variation for WFS among rye genotypes related to differences in the length of the cold acclimation period is similar to observations made in other cereals [56,61]. The switch to inflorescence meristem identity at SAM coincides with an up-regulation of VRN1 expression [9], and VRN1 allele difference is one of the factors determining duration of the vegetative phase in hexaploid wheat [51]. The formation of leaf primordia at the peripheral flank of SAM occurs at auxin maxima see review [62], a process modulated by the relative levels of cytokinin and gibberellin, which display antagonistic effects at SAM [63]. The phytohormone methyl jasmonate (MeJA) is also proposed to affect floral transition time in wheat [64]. Thus, floral transition is strongly affected by phytohormone levels.

The shoot curvature at the base of the crown was not permanently induced by cold as the rye plants reverted back to erect growth habit when growth resumed at normal temperature and long-day conditions. An altered negative gravitropism response resulting in asymmetric distribution of auxin in the shoot was proposed to cause PGH based on studies of gravity persistent signal (gps) mutants in Arabidopsis [65]. Like FLN, PGH is also associated with $V R N 1$ or closely linked $F r-1$ locus on chromosome $5 \mathrm{~A}$ according to early studies of winter wheat [66]. Later studies implicated sensitivity to photoperiod in addition to vernalization sensitivity as the two major factors controlling PGH during juvenile growth in wheat [67]. A role for vernalization requirement was indicated in the study, where winter and perennial types with vernalization requirements developed a stronger PGH than spring and facultative types (Table S2). A role for phytohormone involvement in PGH is supported by studies in barley, for which recessive alleles at the sdw1/denso locus associated with gibberellin biosynthesis induced early prostrate growth in addition to semi-dwarf growth and delayed flowering [68,69]. As phytohormone levels are strongly implicated in the determination of floral transition time and prostrate growth habit during cold acclimation [62,64,70], the influence of $V R N 1$ and/or CBF alleles on genes controlling phytohormone metabolism at SAM are likely to underlie some of the differences in FLN, PGH, and LTT observed for the rye population.

\subsection{WFS and LTT Were Associated with PHT and TIL}

The strong link between LTT and PHT $(r=0.59 ; p<0.001)$, suggested PHT is affected by early events at SAM prior to floral transition. The intercalary meristems, from which leaf initials, axillary buds, and internodes are formed, are laid down during the early stages of SAM development [42], but stem elongation is paused until vernalization, temperature, and photoperiod requirements are fulfilled [71]. A signal transported from the shoot apex is suggested to control internode elongations starting with basal internodes elongating first and the peduncle last [42]. Gibberellin concentrations have a role in stem elongation by 
promoting increased cell division and cell elongations at the intercalary meristems of the stem $[42,46]$. The timing of stem elongation in the spring for winter type is important as early elongation can lead to frost kill due to exhausted LTT at this stage. Like FLN and $\mathrm{PGH}$, a major locus for stem elongation in hexaploid wheat is located close to the $V R N-A 1$ locus on chromosome 5A [71]. PHT and TIL, which showed lower correlation with WFS than FLN and PGH (Table 3), appeared to be related to WFS for only a subgroup of the rye population (Figure 3).

\subsection{DTA Showed Strongest Association with PGH Displayed during Cold Acclimation}

The development of flowers in Triticeae species with fulfilled vernalization requirement starts when photoperiod and temperature requirements are met, which occurs in the spring for winter cereals [72]. At this transition, the up-regulated VRN1 and absence of VRN2 expression in leaves leads to induced expression of VRN3 [73]. VRN3 is the cereal orthologue of Arabidopsis FLOWERING LOCUS T (FT), a transmissible florigen signal promoting flower development [74]. Besides variation for $V R N$ alleles controlling vernalization requirement, allelic differences for PHOTOPERIOD1 (PPD1), circadian clockrelated earliness per se, early maturity, and gibberellin-regulated genes are some of the factors modifying flowering time in cereals (see review [75]). Like many developmental traits associated with WFS, gibberellin levels regulate development of inflorescence into flowers during long days [76]. Thus, the negative correlation between DTA and PHT (and TIL) observed for the rye population could be due to gibberellins stimulating both early flowering (low DTA) and stem elongation (high PHT/TIL). The strong association between DTA and PGH ( $r=0,43 ; p<0.001$; Table 3$)$ suggested genes affecting phytohormone levels at SAM during cold acclimation could also determine flowering time in the spring. Since the developmental traits induced during vernalization and associated with WFS are influenced by plant growth regulators [70], genes affecting phytohormone metabolism at SAM are of prime interest for future WFS studies.

\section{Materials and Methods}

\subsection{Plant Material and Seed Production}

A panel of 96 rye genotypes previously partially characterized for WFS [48] was used in the study (Table 1). The genotypes are represented by 72 winter, 8 spring, 8 facultative, and 8 perennial types and most of them originate from North America or Europe. The genotypes were propagated in growth rooms by seeding in 38-well trays (PL-38-STAR-DP; T.O. Plastics, Clearwater, MN, USA) containing LG3 Propagation Mix (Sungro Horticulture, Agawam, MA, USA) supplemented with $7.3 \mathrm{~g} \mathrm{~L}^{-1}$ slow-release fertilizer Type $100 \mathrm{NPK}$ 14-14-14 (Arysta Lifescience America Inc., Burton, OH, USA) and $1.0 \mathrm{~g} \mathrm{~L}^{-1}$ Micromax micronutrients (ICL Specialty Fertilizers, Dublin, OH, USA). Plant growth to the four-leaf stage was performed under $20 / 18^{\circ} \mathrm{C}$ day/night temperatures, $16 / 8 \mathrm{~h}$ day/night cycle, $50 \%$ relative humidity, and $250 \mu \mathrm{Em}^{-2} \mathrm{~s}^{-1}$ light irradiance. Thereafter, growth was continued at $4{ }^{\circ} \mathrm{C}, 8 / 16 \mathrm{~h}$ day/night cycle, $120 \mu \mathrm{E} \mathrm{m}^{-2} \mathrm{~s}^{-1}$ light intensity, and $50 \%$ humidity to allow for seven weeks' cold acclimation. Acclimated plants were then transplanted into six-inch pots containing soil and slow-release fertilizers as described above and grown to maturity in a greenhouse set at $17 / 7 \mathrm{~h}$ light/dark regime, $1500 \mu \mathrm{E} \mathrm{m} \mathrm{m}^{-2} \mathrm{~s}^{-1}$ light irradiance, $23 / 18{ }^{\circ} \mathrm{C}$ day/night temperatures, and 50\% relative humidity. During the active growth, liquid fertilizer (0.36 $\mathrm{g} \mathrm{L}^{-1}$ NPK 20-20-20) was applied once per week. Pollination control was performed by placing five plants per genotype within a $1.2 \mathrm{~m}^{3}$ pollination bag just prior to anthesis as described [77]. Seeds harvested from mature spikes were stored at room temperature until use.

\subsection{Field Trials for Determination of WFS}

Field trials of 96 rye genotypes (Table 1 ) were conducted at the University of Saskatchewan Experimental Farm, Saskatoon, Saskatchewan, Canada $\left(52^{\circ} 10^{\prime} \mathrm{N}, 106^{\circ} 30^{\prime} \mathrm{W}, 457 \mathrm{~m}\right.$ alti- 
tude) as previously described [48]. Climatological data were collected during the trials (Table S1).

\subsection{Freezing Tests for Determination of LTT}

To determine the LTT (negative $\mathrm{LT}_{50}$ values), freezing tests were performed on the 96 rye genotypes. Cold-hardy winter wheat cv. Norstar was used as internal control. In this assay, plants were grown to four-leaf stage in a growth chamber and cold acclimated for five weeks at $4{ }^{\circ} \mathrm{C}$ as described above. A total of 60 cold-acclimated plants per genotype were then transplanted into five six-inch pots with 12 plants per pot and acclimatized in the dark to $-3{ }^{\circ} \mathrm{C}$ for $12 \mathrm{~h}$ in an EPZ-4H test chamber (ESPEC North America Inc., Hudsonville, MI, USA). Thereafter, the chamber temperature was reduced at a rate of $2.0^{\circ} \mathrm{Ch}^{-1}$. When the first test temperature was reached, one pot per genotype was removed from the freezing chamber and transferred to a $4{ }^{\circ} \mathrm{C}$ growth chamber for thawing. The remaining pots in the freezing chamber were removed one by one upon every $1.5^{\circ} \mathrm{C}$ additional decrease in temperature. For genotypes with highest LTT, the five freezing test temperatures ranged from -24 to $-30{ }^{\circ} \mathrm{C}$, whereas test temperatures ranged from -13.5 to $-19.5^{\circ} \mathrm{C}$ for genotypes with the lowest LTT. The selected test temperatures were predetermined based on WFS data and small-scale freezing tests.

Frost-exposed plants were maintained at $4{ }^{\circ} \mathrm{C}, 8 / 16 \mathrm{~h}$ day /night cycle, $120 \mu \mathrm{E} \mathrm{m}{ }^{-2} \mathrm{~s}^{-1}$ light intensity, and $50 \%$ humidity for $20 \mathrm{~h}$ before being trimmed to one-inch height and transferred to a growth room set at $20 / 18{ }^{\circ} \mathrm{C}$ day /night temperature, $16 / 8 \mathrm{~h}$ day /night cycle, $50 \%$ humidity, and $250 \mu \mathrm{Em}^{-2} \mathrm{~s}^{-1}$ light irradiance. The plants were fertilized once per week with NPK 20-20-20 (35 $\left.\mathrm{g} \mathrm{L}^{-1}\right)$ during watering. After two weeks of regrowth, plant recovery was rated for each of the 60 plants per genotype using a scale from zero to five, where zero indicated no regrowth and five represented full regrowth from all tillers. Average survival scores obtained at each test temperature were plotted against freezing test temperature to generate a kill curve. The freezing temperature at which $50 \%$ of the plants survived was determined as the $\mathrm{LT}_{50}$ value. The freezing tests were performed twice to determine an average $\mathrm{LT}_{50}$ value for each genotype.

\subsection{Collection of Phenotypic Data for Developmental Traits}

The developmental traits FLN, PGH, PHT, TIL, and DTA were assessed on plants cold acclimated in a growth room and grown to maturity in a greenhouse. Each trait was examined in four separate trials with five plants per genotype in each test. To determine FLN, plant leaves were labeled numerically as they developed from the primary stem and the number of the final flag leaf on the main stem was recorded as FLN. PGH was rated for fully cold-acclimated plants by visual scoring of three different growth habits: (1) erect, (2) intermediate, or (3) prostrate. The number of days from the end of cold acclimation and first anther extrusion was recorded as DTA. At maturity, the length of the three longest stems per plant were measured from the soil surface to the top of the head with awn length excluded. The average PHT and TIL were recorded for the genotype. Flag leaf area (FLA) was determined on field-grown plants upon full extension of inflorescence and performed on three plants per genotype with five flag leaves sampled per plant. A LI-3000A Portable Area Meter connected to LI-3050A Transparent Belt Conveyer instrument (LI-COR Inc., Lincoln, NE, USA) was used for the FLA measurements.

\subsection{Statistical Analyses}

The phenotypic data collected were tested for normality using the Minitab 19 Statistical Software (Minitab, LLC, State College, PA, USA). Analysis of variance (ANOVA) was performed by the general linear model using the GEA-R software (Genotype $x$ Environment Analysis with R for Windows) version 4.1 (CIMMYT Research Data \& Software Repository Network El Batan, Mexico). Mean sum of squares from ANOVA were applied to calculate heritability $\left(h^{2}\right)$ for each trait [78]. To determine the overall trait score for each genotype, the Best Linear Unbiased Estimates (BLUEs) were calculated for all the phenotype data 
collected [79]. The calculation was conducted using the statistical analysis software METAR (Multi Environment Trial Analysis with R) version 6.04 (CIMMYT Research Data \& Software Repository Network, El Batan, Mexico). Correlation analyses and principal component analysis (PCA) were conducted using RStudio package version 3.5.1 software [80]. The first two components were used to create bi-plot illustrating the relationships between genotypes and measured traits.

\section{Conclusions}

This study of WFS over five years combined with studies of LTT and six developmental traits showed WFS was almost entirely determined by the cold acclimation process. Thus, variation in WFS among the rye genotypes could to a large extent be explained by differences in the number of leaf initials produced at SAM during cold acclimation, factors inducing PGH in the shoot, and possibly also factors controlling early internode development at SAM. FLA and DTA are traits developed in the spring in winter types and showed no or low association with WFS, but variation for the traits is expected to impact agronomic performance and grain yield. The factors underlying the highly correlated traits FLN, PGH, and maybe also PHT are important to understand development of LTT in winter cereals. A moderate to high heritability displayed by the developmental traits indicated genetics had a large influence on trait values. This also suggests that the highly heritable developmental traits can be used in the selection of lines with high WFS among autumn-seeded rye. With high heritability estimates, good segregation for trait values within the population, and available genome sequence assembly [81], the requirements needed for a genome-wide association study are met [82]. Further genetic studies are expected to reveal the genetic basis for WFS and associated developmental traits for future utilization to enhance WFS in other winter cereals and expand their cultivation in temperate regions.

Supplementary Materials: The following are available online at https:/ /www.mdpi.com/article/10 .3390 /plants10112455/s1. Figure S1: Frequency distribution for WFS data obtained for rye population in five field trials. Correlation analysis is presented in Table 2; Figure S2: Frequency distribution and correlation analysis for FLN data obtained for rye population in four studies; Figure S3: Frequency distribution and correlation analysis for PGH data obtained for rye population in four studies. Phenotypes scored for PGH is shown; Figure S4: Frequency distribution and correlation analysis for days to DTA data obtained for rye population in four studies; Figure S5: Frequency distribution and correlation analysis for PHT data obtained for rye population in four studies; Figure S6: Frequency distribution and correlation analysis TIL data obtained for rye population in four studies; Figure S7: Frequency distribution and correlation analysis for FLA data obtained for rye population in four field trials; Figure S8: PCA bi-plot of rye genotypes based on PCA1 and PCA2 components and vectors of traits analyzed in the study. Genotypes with winter $(\mathrm{W})$, spring $(\mathrm{S})$, facultative $(\mathrm{F})$, and perennial $(\mathrm{P})$ growth habit are indicated; Table S1: Local climatological data during consecutive growing seasons 2014 to 2019; Table S2: Development trait data for different growth habit classes of rye.

Author Contributions: H.B.: investigation, formal analysis, writing original draft. M.B.: conceptualization, funding acquisition, methodology, resources, writing-review and editing: J.L.: conceptualization, resources, funding acquisition, review. R.J.G.: conceptualization, funding acquisition, review. A.L.: conceptualization, funding acquisition, review. R.N.C.: conceptualization, funding acquisition, supervision, project administration, writing - review and editing. All authors have read and agreed to the published version of the manuscript.

Funding: This work was supported by the Canada Research Chairs (RNC), Natural Sciences and Engineering Research Council Canada (NSERC) Discovery grant (RNC), NSERC collaborative research project grant with Western Grains Research Foundation, Saskatchewan Winter Cereals Development Commission, Winter Cereals Manitoba Inc. and Alberta Wheat Commission, and the NSERC Alliance grant with Western Grains Research Foundation and Saskatchewan Winter Cereals Development Commission. HB is a grateful recipient of the Harvey scholarship and Devolved scholarship awarded by the Department of Plant Sciences, University of Saskatchewan.

Institutional Review Board Statement: Ethical review and approval were not needed for this study. 
Informed Consent Statement: Not applicable.

Data Availability Statement: All data is included in the manuscript text and Supplementary Tables.

Acknowledgments: Several research technicians and summer students over the last six years are acknowledged for help with the field and greenhouse work.

Conflicts of Interest: The authors declare no conflict of interest.

\section{References}

1. Haffke, S.; Kusterer, B.; Fromme, F.J.; Roux, S.; Hackauf, B.; Miedaner, T. Analysis of covariation of grain yield and dry matter yield for breeding dual use hybrid rye. BioEnergy Res. 2014, 7, 424-429. [CrossRef]

2. Newell, M.A.; Butler, T.J. Forage rye improvement in the southern United States: A review. Crop Sci. 2013, 53, 38-47. [CrossRef]

3. Schlegel, R. Hybrid breeding boosted molecular genetics in rye. Russ. J. Genet. Appl. Res. 2016, 6, 569-583. [CrossRef]

4. Schlegel, R.H.J. RYE: Genetics, Breeding, and Cultivation; CRC Press: Boca Raton, FL, USA, 2014.

5. von Zitzewitz, J.; Szúcs, P.; Dubcovsky, J.; Yan, L.; Francia, E.; Pecchioni, N.; Casas, A.; Chen, T.H.H.; Hayes, P.M.; Skinner, J.S. Molecular and structural characterization of barley vernalization genes. Plant Mol. Biol. 2005, 59, 449-467. [CrossRef] [PubMed]

6. Gruner, P.; Miedaner, T. Perennial rye: Genetics of perenniality and limited fertility. Plants 2021, 10, 1210. [CrossRef] [PubMed]

7. Cao, S.; Luo, X.; Xu, D.; Tian, X.; Song, J.; Xia, X.; Chu, C.; He, Z. Genetic architecture underlying light and temperature mediated flowering in Arabidopsis, rice, and temperate cereals. New Phytol. 2021, 230, 1731-1745. [CrossRef]

8. Trevaskis, B.; Bagnall, D.J.; Ellis, M.H.; Peacock, W.J.; Dennis, E.S. MADS box genes control vernalization-induced flowering in cereals. Proc. Natl. Acad. Sci. USA 2003, 100, 13099-13104. [CrossRef]

9. Yan, L.; Loukoianov, A.; Tranquilli, G.; Helguera, M.; Fahima, T.; Dubcovsky, J. Positional cloning of the wheat vernalization gene VRN1. Proc. Natl. Acad. Sci. USA 2003, 100, 6263-6268. [CrossRef]

10. Yan, L.; Loukoianov, A.; Blechl, A.; Tranquilli, G.; Ramakrishna, W.; SanMiguel, P.; Bennetzen, J.L.; Echenique, V.; Dubcovsky, J. The wheat VRN2 gene is a flowering repressor down-regulated by vernalization. Science 2004, 303, 1640-1644. [CrossRef]

11. Yan, L.; Fu, D.; Li, C.; Blechl, A.; Tranquilli, G.; Bonafede, M.; Sanchez, A.; Valarik, M.; Yasuda, S.; Dubcovsky, J. The wheat and barley vernalization gene VRN3 is an orthologue of FT. Proc. Natl. Acad. Sci. USA 2006, 103, 19581-19586. [CrossRef]

12. Chen, A.; Dubcovsky, J. Wheat TILLING mutants show that the vernalization gene VRN1 down-regulates the flowering repressor VRN2 in leaves but is not essential for flowering. PLoS Genet. 2012, 8, e1003134. [CrossRef]

13. Sasani, S.; Hemming, M.N.; Oliver, S.N.; Greenup, A.; Tavakkol-Afshari, R.; Mahfoozi, S.; Poustini, K.; Sharifi, H.-R.; Dennis, E.S.; Peacock, W.J.; et al. The influence of vernalization and daylength on expression of flowering-time genes in the shoot apex and leaves of barley (Hordeum vulgare). J. Exp. Bot. 2009, 60, 2169-2178. [CrossRef] [PubMed]

14. Mahfoozi, S.; Limin, A.E.; Fowler, D.B. Developmental regulation of low-temperature tolerance in winter wheat. Ann. Bot. 2001, 87, 751-757. [CrossRef]

15. Diallo, A.O.; Ali-Benali, M.A.; Badawi, M.; Houde, M.; Sarhan, F. Expression of vernalization responsive genes in wheat is associated with histone H3 trimethylation. Mol. Genet. Genom. 2012, 287, 575-590. [CrossRef] [PubMed]

16. Greenup, A.G.; Sasani, S.; Oliver, S.N.; Talbot, M.J.; Dennis, E.S.; Hemming, M.N.; Trevaskis, B. ODDSOC2 is a MADS box floral repressor that is down-regulated by vernalization in temperate cereals. Plant Physiol. 2010, 153, 1062-1073. [CrossRef]

17. Ruelens, P.; De Maagd, R.A.; Proost, S.; Theißen, G.; Geuten, K.; Kaufmann, K. FLOWERING LOCUS C in monocots and the tandem origin of angiosperm-specific MADS-box genes. Nat. Commun. 2013, 4, 2280. [CrossRef] [PubMed]

18. Winfield, M.O.; Lu, C.; Wilson, I.D.; Coghill, J.A.; Edwards, K.J. Cold- and light-induced changes in the transcriptome of wheat leading to phase transition from vegetative to reproductive growth. BMC Plant Biol. 2009, 9, 55. [CrossRef] [PubMed]

19. Kennedy, A.; Geuten, K. The role of FLOWERING LOCUS C relatives in cereals. Front. Plant Sci. 2020, 11, 617340. [CrossRef]

20. Dhillon, T.; Pearce, S.P.; Stockinger, E.J.; Distelfeld, A.; Li, C.; Knox, A.K.; Vashegyi, I.; Vágújfalvi, A.; Galiba, G.; Dubcovsky, J. Regulation of freezing tolerance and flowering in temperate cereals: The VRN-1 connection. Plant Physiol. 2020, 153, 1846-1858. [CrossRef]

21. Stockinger, E.J.; Skinner, J.S.; Gardner, K.G.; Francia, E.; Pecchioni, N. Expression levels of barley Cbf genes at the Frost resistance-H2 locus are dependent upon alleles at Fr-H1 and Fr-H2. Plant J. 2007, 51, 308-321. [CrossRef]

22. Guy, C.; Kaplan, F.; Kopka, J.; Selbig, J.; Hincha, D.K. Metabolomics of temperature stress. Physiol. Plant. 2008, 132, 220-235. [CrossRef]

23. Hüner, N.P.A.; Bode, R.; Dahal, K.; Hollis, L.; Rosso, D.; Krol, M.; Ivanov, A.G. Chloroplast redox imbalance governs phenotypic plasticity: The "grand design of photosynthesis" revisited. Front. Plant Sci. 2012, 3, 255. [CrossRef] [PubMed]

24. Uemura, M.; Tominaga, Y.; Nakagawara, C.; Shigematsu, S.; Minami, A.; Kawamura, Y. Responses of the plasma membrane to low temperatures. Physiol. Plant. 2006, 126, 81-89. [CrossRef]

25. Francia, E.; Barabaschi, D.; Tondelli, A.; Laidò, G.; Rizza, F.; Stanca, A.M.; Busconi, M.; Fogher, C.; Stockinger, E.J.; Pecchioni, N. Fine mapping of a $\mathrm{HvCBF}$ gene cluster at the frost resistance locus Fr-H2 in barley. Theor. Appl. Genet. 2007, 115, 1083-1091. [CrossRef] [PubMed]

26. Galiba, G.; Vágújfalvi, A.; Li, C.; Soltész, A.; Dubcovsky, J. Regulatory genes involved in the determination of frost tolerance in temperate cereals. Plant Sci. 2009, 176, 12-19. [CrossRef] 
27. Vágújfalvi, A.; Aprile, A.; Miller, A.; Dubcovsky, J.; Delugu, G.; Galiba, G.; Cattivelli, L. The expression of several Cbf genes at the Fr-A2 locus is linked to frost resistance in wheat. Mol. Genet. Genom. 2005, 274, 506-514. [CrossRef]

28. Kosová, K.; Prášil, I.T.; Vítámvás, P. The relationship between vernalization- and photoperiodically-regulated genes and the development of frost tolerance in wheat and barley. Biol. Plant. 2008, 52, 601-615. [CrossRef]

29. Fowler, D.B.; Byrns, B.M.; Greer, K.J. Overwinter low-temperature responses of cereals: Analyses and simulation. Crop Sci. 2014, 54, 2395-2405. [CrossRef]

30. Skinner, D.Z.; Bellinger, B.S. Differential response of wheat cultivars to components of the freezing process in saturated soil. Crop Sci. 2011, 51, 69. [CrossRef]

31. Rapacz, M.; Jurczyk, B.; Sasal, M. Deacclimation may be crucial for winter survival of cereals under warming climate. Plant Sci. 2017, 256, 5-15. [CrossRef]

32. Ponomareva, M.L.; Gorshkov, V.Y.; Ponomarev, S.N.; Korzun, V.; Miedaner, T. Snow mold of winter cereals: A complex disease and a challenge for resistance breeding. Theor. Appl. Genet. 2021, 134, 419-433. [CrossRef] [PubMed]

33. Gu, L.; Hanson, P.J.; Post, W.M.; Kaiser, D.P.; Yang, B.; Nemani, R.; Pallardy, S.G.; Meyers, T. The 2007 eastern US spring freeze: Increased cold damage in a warming world? Bioscience 2008, 58, 253-262. [CrossRef]

34. Trnka, M.; Rötter, R.P.; Ruiz-Ramos, M.; Kersebaum, K.C.; Olesen, J.E.; Žalud, Z.; Semenov, M.A. Adverse weather conditions for European wheat production will become more frequent with climate change. Nat. Clim. Chang. 2014, 4, 637-643. [CrossRef]

35. Båga, M.; Fowler, D.B.; Chibbar, R.N. Identification of genomic regions determining the phenological development leading to floral transition in wheat (Triticum aestivum L.). J. Exp. Bot. 2009, 60, 3575-3585. [CrossRef] [PubMed]

36. Fowler, D.B.; Limin, A.E.; Mahfoozi, S.; Sarhan, F. Photoperiod and temperature interactions regulate low-temperature-induced gene expression in barley. Plant Physiol. 2001, 127, 1676-1681. [CrossRef] [PubMed]

37. Limin, A.E.; Fowler, D.B. Morphological and cytological characters associated with low-temperature tolerance in wheat (Triticum aestivum L. em Thell.). Can. J. Plant Sci. 2000, 80, 687-692. [CrossRef]

38. Körner, C. Plant adaptation to cold climates. F1000Research 2016, 5, 2769. [CrossRef]

39. Tan, L.; Li, X.; Liu, F.; Sun, X.; Li, C.; Zhu, Z.; Fu, Y.; Cai, H.; Wang, X.; Xie, D.; et al. Control of a key transition from prostrate to erect growth in rice domestication. Nat. Genet. 2008, 40, 1360-1364. [CrossRef]

40. Quarrie, S.A.; Quarrie, P.S.; Radosevic, R.; Rancic, D.; Kaminska, A.; Barnes, J.D.; Leverington, M.; Ceoloni, C.; Dodig, D. Dissecting a wheat QTL for yield present in a range of environments: From the QTL to candidate genes. J. Exp. Bot. 2006, 57, 2627-2637. [CrossRef]

41. Kirby, E.J.M.; Appleyard, M.; Simpson, N.A. Co-ordination of stem elongation and Zadoks growth stages with leaf emergence in wheat and barley. J. Agric. Sci. 1994, 122, 21-29. [CrossRef]

42. McKim, S.M. How plants grow up. J. Integr. Plant Biol. 2019, 61, 257-277. [CrossRef] [PubMed]

43. Braun, E.-M.; Tsvetkova, N.; Rotter, B.; Siekmann, D.; Schwefel, K.; Krezdorn, N.; Plieske, J.; Winter, P.; Melz, G.; Voylokov, A.V.; et al. Gene expression profiling and fine mapping identifies a gibberellin 2-oxidase gene co-segregating with the dominant dwarfing gene Ddw1 in rye (Secale cereale L.). Front. Plant Sci. 2019, 10, 857. [CrossRef] [PubMed]

44. Grądzielewska, A.; Milczarski, P.; Molik, K.; Pawłowska, E. Identification and mapping of a new recessive dwarfing gene $d w 9$ on the 6RL rye chromosome and its phenotypic effects. PLoS ONE 2020, 15, e0229564. [CrossRef]

45. Hellewell, K.B.; Rasmusson, D.C.; Gallo-Meagher, M. Enhancing yield of semi-dwarf barley. Crop Sci. 2000, 40, 352-358. [CrossRef]

46. Peng, J.; Richards, D.E.; Hartley, N.M.; Murphy, G.P.; Devos, K.M.; Flintham, J.E.; Beales, J.; Fish, L.J.; Worland, A.J.; Pelica, F.; et al. "Green revolution" genes encode mutant gibberellin response modulators. Nature 1999, 400, 256-261. [CrossRef]

47. Sang, M.; Shi, H.; Wei, K.; Ye, M.; Jiang, L.; Sun, L.; Wu, R. A dissection model for mapping complex traits. Plant J. 2019, 97, 1168-1182. [CrossRef] [PubMed]

48. Bahrani, H.; Thoms, K.; Båga, M.; Larsen, J.; Graf, R.; Laroche, A.; Sammynaiken, R.; Chibbar, R.N. Preferential accumulation of glycosylated cyanidins in winter-hardy rye (Secale cereale L.) genotypes during cold acclimation. Environ. Exp. Bot. 2019, 164, 203-212. [CrossRef]

49. Acharya, S.N.; Mir, Z.; Moyer, J.R. ACE-1 perennial cereal rye. Can. J. Plant Sci. 2004, 84, 819-821. [CrossRef]

50. Knox, A.K.; Li, C.; Vágújfalvi, A.; Galiba, G.; Stockinger, E.J.; Dubcovsky, J. Identification of candidate CBF genes for the frost tolerance locus Fr-A $A^{m} 2$ in Triticum monococcum. Plant Mol. Biol. 2008, 67, 257-270. [CrossRef]

51. Zhu, J.; Pearce, S.; Burke, A.; See, D.R.; Skinner, D.Z.; Dubcovsky, J.; Garland-Campbell, K. Copy number and haplotype variation at the $V R N-A 1$ and central FR-A2 loci are associated with frost tolerance in hexaploid wheat. Theor. Appl. Genet. 2014, 127, 1183-1197. [CrossRef]

52. Francia, E.; Morcia, C.; Pasquariello, M.; Mazzamurro, V.; Milc, J.A.; Rizza, F.; Terzi, V.; Pecchioni, N. Copy number variation

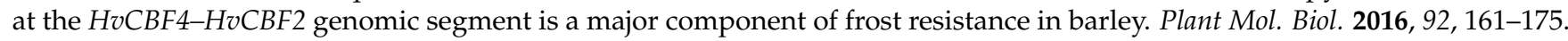
[CrossRef]

53. Rizza, F.; Karsai, I.; Morcia, C.; Badeck, F.-W.; Terzi, V.; Pagani, D.; Kiss, T.; Stanca, A.M. Association between the allele compositions of major plant developmental genes and frost tolerance in barley (Hordeum vulgare L.) germplasm of different origin. Mol. Breed. 2016, 36, 156. [CrossRef]

54. Erath, W.; Bauer, E.; Fowler, D.B.; Gordillo, A.; Korzun, V.; Ponomareva, M.; Schmidt, M.; Schmiedchen, B.; Wilde, P.; Schön, C.-C. Exploring new alleles for frost tolerance in winter rye. Theor. Appl. Genet. 2017, 130, 2151-2164. [CrossRef] 
55. Li, Y.; Böck, A.; Haseneyer, G.; Korzun, V.; Wilde, P.; Schön, C.-C.; Ankerst, D.P.; Bauer, E. Association analysis of frost tolerance in rye using candidate genes and phenotypic data from controlled, semi-controlled, and field phenotyping platforms. BMC Plant Biol. 2011, 11, 146. [CrossRef]

56. Fowler, D.; Chauvin, L.; Limin, A.; Sarhan, F. The regulatory role of vernalization in the expression of low-temperature-induced genes in wheat and rye. Theor. Appl. Genet. 1996, 93, 554-559. [CrossRef]

57. Ganeshan, S.; Vitamvas, P.; Fowler, D.B.; Chibbar, R.N. Quantitative expression analysis of selected COR genes reveals their differential expression in leaf and crown tissues of wheat (Triticum aestivum L.) during an extended low temperature acclimation regimen. J. Exp. Bot. 2008, 59, 2393-2402. [CrossRef]

58. Mayer, B.F.; Bertrand, A.; Charron, J.-B. Treatment analogous to seasonal change demonstrates the integration of cold responses in Brachypodium distachyon. Plant Physiol. 2020, 182, 1022-1038. [CrossRef]

59. Leuendorf, J.E.; Frank, M.; Schmülling, T. Acclimation, priming and memory in the response of Arabidopsis thaliana seedlings to cold stress. Sci. Rep. 2020, 10, 689. [CrossRef]

60. Gaudet, D.A.; Laroche, A.; Yoshida, M. Low temperature-wheat-fungal interactions: A carbohydrate connection. Physiol. Plant. 1999, 106, 437-444. [CrossRef]

61. Fowler, D.B.; Limin, A.E. Interactions among factors regulating phenological development and acclimation rate determine low-temperature tolerance in wheat. Ann. Bot. 2004, 94, 717-724. [CrossRef]

62. Kuhlemeier, C. Phyllotaxis. Curr. Biol. 2017, 27, R882-R887. [CrossRef] [PubMed]

63. Galinha, C.; Bilsborough, G.; Tsiantis, M. Hormonal input in plant meristems: A balancing act. Semin. Cell Dev. Biol. 2009, 20, 1149-1156. [CrossRef] [PubMed]

64. Diallo, A.O.; Agharbaoui, Z.; Badawi, M.A.; Ali-Benali, M.A.; Moheb, A.; Houde, M.; Sarhan, F. Transcriptome analysis of an mop mutant reveals important changes in global gene expression and a role for methyl jasmonate in vernalization and flowering in wheat. J. Exp. Bot. 2014, 65, 2271-2286. [CrossRef] [PubMed]

65. Wyatt, S.E.; Rashotte, A.M.; Shipp, M.J.; Robertson, D.; Muday, G.K. Mutations in the gravity persistence signal loci in Arabidopsis disrupt the perception and/or signal transduction of gravitropic stimuli. Plant Physiol. 2002, 130, 1426-1435. [CrossRef]

66. Roberts, D.W.A. Identification of loci on chromosome 5A of wheat involved in control of cold hardiness, vernalization, leaf length, rosette growth habit, and height of hardened plants. Genome 1990, 33, 247-259. [CrossRef]

67. Marone, D.; Rodriguez, M.; Saia, S.; Papa, R.; Rau, D.; Pecorella, I.; Laidò, G.; Pecchioni, N.; Lafferty, J.; Rapp, M.; et al. Genomewide association mapping of prostrate/erect growth habit in winter durum wheat. Int. J. Mol. Sci. 2020, 21, 394. [CrossRef] [PubMed]

68. Kuczyńska, A.; Mikołajczak, K.; Ćwiek, H. Pleiotropic effects of the sdw1 locus in barley populations representing different rounds of recombination. Electron. J. Biotechnol. 2014, 17, 217-223. [CrossRef]

69. Zhou, Y.; Zhou, G.; Broughton, S.; Westcott, S.; Zhang, X.; Xu, Y.; Xu, L.; Li, C.; Zhang, W. Towards the identification of a gene for prostrate tillers in barley (Hordeum vulgare L.). PLoS ONE 2018, 13, e0192263. [CrossRef]

70. Eremina, M.; Rozhon, W.; Poppenberger, B. Hormonal control of cold stress responses in plants. Cell. Mol. Life Sci. 2016, 73, 797-810. [CrossRef]

71. Chen, Y.; Carver, B.F.; Wang, S.; Zhang, F.; Yan, L. Genetic loci associated with stem elongation and winter dormancy release in wheat. Theor. Appl. Genet. 2009, 118, 881-889. [CrossRef]

72. Trevaskis, B.; Hemming, M.N.; Dennis, E.S.; Peacock, W.J. The molecular basis of vernalization-induced flowering in cereals. Trends Plant Sci. 2007, 12, 352-357. [CrossRef]

73. Deng, W.; Casao, M.C.; Wang, P.; Sato, K.; Hyes, P.M.; Finnegan, E.J.; Trevaskis, B. Direct links between the vernalization response and other key traits of cereal crops. Nat. Commun. 2015, 6, 6882. [CrossRef] [PubMed]

74. Corbesier, L.; Vincent, C.; Jang, S.; Fornara, F.; Fan, Q.; Searle, I.; Giakountis, A.; Farrona, S.; Gissot, L.; Turnbull, C.; et al. FT protein movement contributes to long-distance signaling in floral induction of Arabidopsis. Science 2007, 316, 1030-1033. [CrossRef] [PubMed]

75. Hill, C.B.; Li, C. Genetic architecture of flowering phenology in cereals and opportunities for crop improvement. Front. Plant Sci. 2016, 7, 1906. [CrossRef] [PubMed]

76. Boden, S.A.; Weiss, D.; Ross, J.J.; Davies, N.W.; Trevaskis, B.; Chandler, P.M.; Swain, S.M. EARLY FLOWERING3 regulates flowering in spring barley by mediating gibberellin production and FLOWERING LOCUS T expression. Plant Cell 2014, 26, 1557-1569. [CrossRef] [PubMed]

77. Vogel, K.P.; Sarath, G.; Mitchell, R.B. Micromesh fabric pollination bags for switchgrass. Crop Sci. 2014, 54, 1621-1623. [CrossRef]

78. Singh, M.; Ceccarelli, S.; Hamblin, J. Estimation of heritability from varietal trials data. Theor. Appl. Genet. 1993, 86, 437-441. [CrossRef]

79. Piepho, H.P.; Richter, C.; Williams, E. Nearest neighbour adjustment and linear variance models in plant breeding trials. Biom. J. 2008, 50, 164-189. [CrossRef]

80. Chavent, M.; Kuentz-Simonet, V.; Saracco, J. Orthogonal rotation in PCAMIX. Adv. Data Anal. Classif. 2012, 6, 131-146. [CrossRef]

81. Rabanus-Wallace, M.T.; Hackauf, B.; Mascher, M.; Lux, T.; Wicker, T.; Gundlach, H.; Baez, M.; Houben, A.; Mayer, K.F.; Guo, L.; et al. Chromosome-scale genome assembly provides insights into rye biology, evolution and agronomic potential. Nat. Genet. 2021, 53, 564-573. [CrossRef]

82. Alqudah, A.M.; Sallam, A.; Baenziger, P.S.; Börner, A. GWAS: Fast-forwarding gene identification and characterization in temperate cereals: Lessons from barley-A review. J. Adv. Res. 2020, 22, 119-135. [CrossRef] [PubMed] 